\title{
Spatio-Temporal Climate and Agroclimate Diversities over the Zagreb City Area
}

\author{
Darija Bilandžija ${ }^{\mathrm{A}}$ \\ Received: November 30, 2019 | Revised: December 29, 2019 | Accepted: December 30, 2019 \\ DOI: 10.5937/gp23-24253
}

\begin{abstract}
The Zagreb city is rich in green urban infrastructure that has an important role in climate change mitigation and adaptation. Knowledge on climate change and agroclimate has an important role in planning of green areas. Therefore, the aim is to evaluate the temporal and spatial diversities of agroclimate indicators over Zagreb city. Warming and no change in mean annual precipitation, as well as prolonged vegetation periods and reduced evapotranspiration were observed at all locations in the recent 19912018 compared to reference 1961-1990 period. The results indicate different intensity in climate change of observed indicators and existance of diffrences in indicators between city centre, suburb and hilly slopes thatshould be considered while planning green urban infracture.
\end{abstract}

Keywords: agroclimate indicators; climate change; precipitation; temperature; hydrothermal conditions; water balance; Zagreb

\section{Introduction}

Green urban infrastructure has important role in the context of climate change mitigation and adaptation. According to Demuzere et al (2014) green urban infrastructure contributes to the physical, psychological and social benefits, i.e. $\mathrm{CO}_{2}$ reduction, thermal comfort and reduced energy use, health and restorative benefits, social and individual coping capacities and education. Green urban infrastructure contributes to climate change mitigation by sequestration of atmospheric carbon into the soil and plant pool via the process of photosynthesis. Additional uptake can occur via below-ground biomass and soils (Velasco and Roth, 2010). Furthermore, urban ecosystems can have a role in climate change adaptation by reducing air and surface temperature as they provide shading (Takacs et al., 2016) and enhance the evapotranspiration that results in energy use reduction and improved thermal comfort (Bajšanski et al., 2015; Ongoma et al., 2016; Milošević et al., 2017a;). The vegetation in urban areas also affects air and water quality as it absorbs pollutants. These services are relevant to urban areas for adapting to climate change and the dynamics of human requirements (Farrugia et al., 2013). Green urban infrastructure provides a range of recreational and psychological benefits, as well as opportunities for community education how to adapt to climate change.

The Zagreb city is in the inland region of Croatia which has a temperate continental climate (Zaninović et al., 2008). During the entire year it is in circulation belt of mid-latitude where the state of the atmosphere is very variable. It is marked by a variety of weather situations with frequent and intense changes during the year. They are caused by atmospheric systems of low or high air pressure, often like vortexes with diameter hundreds and thousands of kilometres. In the cold season, stationary anticyclonic weather types with foggy weather or low cloudiness with very low flow prevail. Summer is dominated by pressure fields with small pressure gradient accompanied by weak

A University of Zagreb Faculty of Agriculture, Department of General Agronomy, Svetošimunska cesta 25, 10000 Zagreb, Croatia; Darija Bilandžija; e-mail: dbilandzija@agr.hr; Tel: +385 1239 4089; Fax: +385 12393981 
wind, but with unstable stratification of the atmosphere. Turbulent air mixing is very strong, convective clouds develop and the possibility of rain shower. Fast moving cyclonic weather types (cyclones and pressure troughs) are typical for spring leading to frequent and sudden changes of weather, and exchange of rainy periods and those with no rain. Local climate is is modified by the weak maritime influence of the Mediterranean, as well as by the orography of the Alps and the Dinaric Alps. Medvednica Mountain and the mountains in the NW part of Croatia - Hrvatsko Zagorje have the immediate influence. They facilitate the intensification of short-term heavy precipitation on the windward side of the orographic obstacle. Medvednica Mountain acts as a barrier to the northwest precipitation outbreaks and may cause shortterm intensification of heavy precipitation or may create precipitation shadow in the eastern part of Zagreb (Gajić-Čapka, 1982; Gajić-Čapka and Cindrić, 2008; Sokol Jurković, 2011).

According to the Köppen climate classification, the area of Zagreb has a temperate rainy climate (Cfwbx") like most of Croatia (Penzar and Penzar, 2010). Za- greb area has average air temperature of $10.9^{\circ} \mathrm{C}$, apsolute maximal temperature of $40.4^{\circ} \mathrm{C}$, apsolute minimal temperature of $-27.3{ }^{\circ} \mathrm{C}$, precipitation amount of $859.4 \mathrm{~mm}, 6$ number of days with snow and 11 number of days with frost in the period 1949-2018 (DHMZ, 2019).

The city of Zagreb is rich in green spaces: parks, gardens, park-forests, orchards and vineyards in the downtown and suburbs both in the lowlands and on the slopes of Medvednica Mountain (highest peak Sljeme - $1033 \mathrm{~m}$ a.s.l.). As climate and consequently agroclimate are important parts of the resource base for green urban horticulture, gardening, fruit and vine growing, the information and knowledge on climate as well as climate change should be incorporated into the strategic urban plans and the maintenance of existing green spaces. Therefore, the aim of the paper is to evaluate the temporal (1961-1990 and 1991-2018) and spatial (city centre, suburb and hilly slopes) variability of meteorological (air temperature, precipitation amount) and agroclimatic (rain factor, water balance, aridity index, cardinal temperatures) indicators over the Zagreb city area.

\section{Data and methods}

According to the recommendations of the World Meteorological Organization (WMO) Guide to Climatological Practices (WMO, 2011) and the WMO Technical Regulations (WMO, 2012) as well as the recommendation of the $16^{\text {th }}$ Commission for Climatology (Commission for Climatology-CCl) with WMO in 2014, a 30-year data series is further used to display the climatic conditions. In doing so, the period 19611990 serves as a reference climatic period, especially in the analyses of climate change. In order to display the climatic conditions, later 30-year periods beginning with the year ending with the number 1: 19712000 and 1981-2010 can be used. This enables the spatial comparison of simultaneous climatic conditions at different locations or regions.

The present analysis deals with the comparison of two periods: the reference period 1961-1990 and the recent available 28 - year period 1991-2018 for the selected meteorological (air temperature and precipitation) as well as agroclimatic indicators (rain factor, cardi-

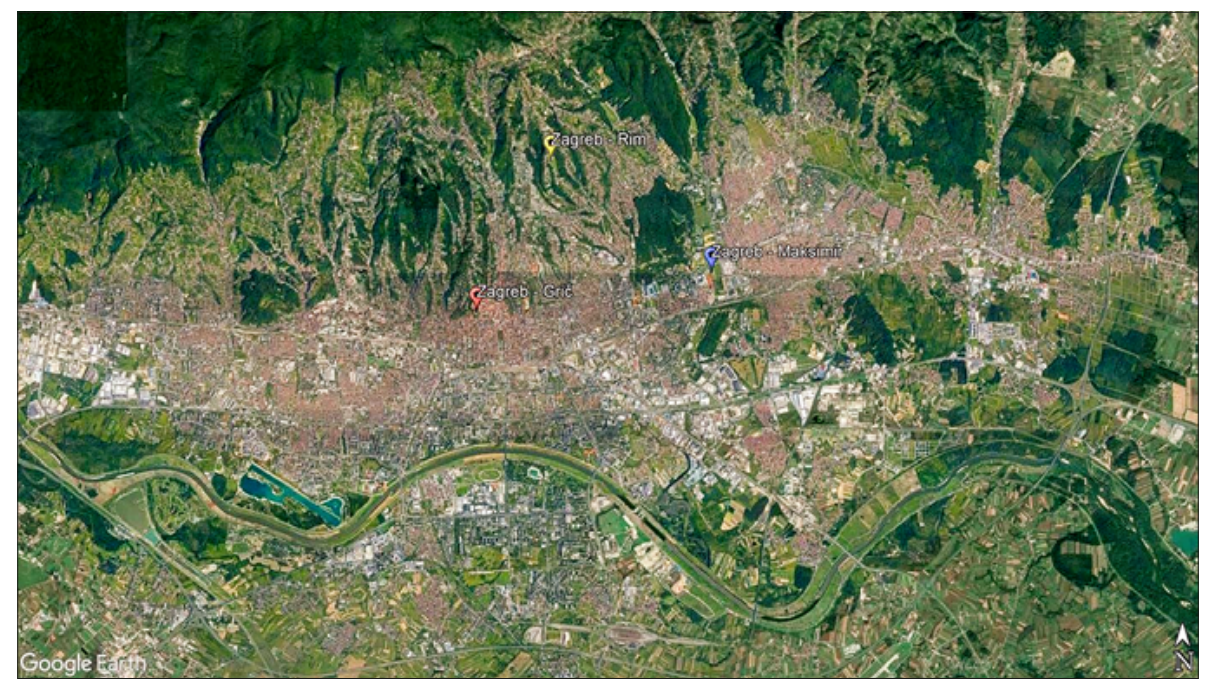

Figure 1. Locations of Zagreb-Grič (ZG), Zagreb-Maksimir (ZM) and Zagreb-Rim (ZR) meteorological stations over the Zagreb city 
nal temperatures, water balance and index of aridity) for three locations over the Zagreb city area. The data used in this research are obtained from meteorological stations that are part of the regular network of Meteorological and Hydrological Service of Croatia. Meteorological stations are categorized in adequate local climate zone according to Stewart and Oke (2012) based on the authors knowledge of local climate and urbanization characteristics. Zagreb-Grič (ZG) $(\mathrm{H}=$ $157 \mathrm{~m}$ a.s.l., $\phi=45^{\circ} 48^{\prime} 52^{\prime \prime} \mathrm{N}, \lambda=15^{\circ} 58^{\prime} 19^{\prime \prime} \mathrm{E}$ ) is located in the upper town of the central urban part (local climate zone $6 \mathrm{~B})$, Zagreb-Maksimir $(\mathrm{ZM})(\mathrm{H}=123 \mathrm{~m}$ a.s.l., $\left.\phi=45^{\circ} 49^{\prime} 19^{\prime \prime} \mathrm{N}, \lambda=16^{\circ} \mathrm{O} 2^{\prime} \mathrm{o1} 1^{\prime \prime} \mathrm{E}\right)$ in the eastern suburb where the urbanization takes place (local climate zone $8 \mathrm{D})$, and Zagreb-Rim (ZR) $(\mathrm{H}=220 \mathrm{~m}$ a.s.l., $\phi=45^{\circ} 50^{\prime} \mathrm{N}, \lambda=16^{\circ} \mathrm{oo} \mathrm{o}^{\prime} \mathrm{E}$ ) on the slopes of Medvednica Mountain that extends north of the city (local climate zone ${ }_{9} \mathrm{D}$ ). The locations of the meteorological stations are presented at Figure 1.

Overview of climate and agroclimatic conditions includes the average annual variation in observed parameters: air temperature, precipitation amount, rain factor, index of aridity and beginning and the end of the vegetation period for selected cardinal temperatures. This points to the seasonal changes of mean values. The Lang's rain factor (RF) and Gračanin's monthly rain factor (RFm) are calculated according to Gračanin (1950) and interpreted as presented in Bilandžija et al. (2019.):

$$
R F=\frac{P y}{T y} \quad R F m=\frac{P m}{T m}
$$

where:

- $P y$ - annual rainfall amount $(\mathrm{mm})$

- Ty - average annual temperature $\left({ }^{\circ} \mathrm{C}\right)$

- Pm - monthly rainfall amount (mm)

- Tm - average monthly temperature $\left({ }^{\circ} \mathrm{C}\right)$
Thresholds of cardinal temperatures for the beginning and the end of vegetation periods with the temperatures above $5,10,15$ and $20^{\circ} \mathrm{C}$ are calculated according to Butorac (1976):

The beginning of the period with temperature above cardinal $\left(5,10,15\right.$ and $\left.20^{\circ} \mathrm{C}\right)$ :

$$
n=\frac{T b-T a}{30} \quad x=\frac{T c-T a}{n}
$$

The end of the period with temperature above cardinal $\left(5,10,15\right.$ and $\left.20^{\circ} \mathrm{C}\right)$ :

$$
n=\frac{T b-T c}{30} \quad x=\frac{T b-T c}{n}
$$

where:

- $T a$ - temperature at the beginning/end of the period closest to the cardinal but lower than it

- $\mathrm{Tb}$ - temperature (at the beginning/end of the period) closest to the cardinal but higher than it

- $T c$ - cardinal temperature $\left(5,10,15\right.$ or $\left.20^{\circ} \mathrm{C}\right)$

- $x$ - number of days to be added to the middle of the month with temperature a (for the beginning of the period) or with temperature $b$ (for the end of the period)

Water balance is calculated according to Thorntwhite method (Penzar and Penzar, 200o) and drought conditions were described by monthly index of aridity created by UNEP for numerical identification of desertification (UNEP, 1992; Perčec Tadić et al., 2013):

$$
I A U=\frac{P}{P E T}
$$

where:

- $P$ - precipitation $(\mathrm{mm})$

- PET - potential evapotranspiration according to Thorntwhite method (mm)

\section{Results and discussion}

\section{Air temperature}

According to the data from the recent 28-year period 1991-2018 average annual cycle of mean monthly temperatures has a shape of an one-strand wave with a maximum in summer, most often in July $\left(Z G=23.1^{\circ} \mathrm{C}\right.$,

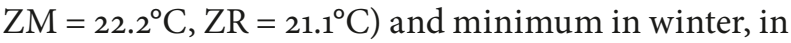
January $\left(\mathrm{ZG}=2.5^{\circ} \mathrm{C}, \mathrm{ZM}=1.4^{\circ} \mathrm{C}, \mathrm{ZR}=0.0^{\circ} \mathrm{C}\right)(\mathrm{Fig}$ ure 2). Continental characteristics are prevailing in the annual cycle and they are reflected in the warmer spring than autumn, with a small differences, spring beeing warmer than autumn $\left(\mathrm{ZG}=0.1^{\circ} \mathrm{C}, \mathrm{ZM}=0.1^{\circ} \mathrm{C}\right.$,
$\mathrm{ZR}=0.2^{\circ} \mathrm{C}$ ). Average annual cycle of mean monthly temperatures at Zagreb-Grič (ZG) in the upper town of the central urban area is $0.7^{\circ} \mathrm{C}$ to $1.4^{\circ} \mathrm{C}$ warmer than monthly means at Zagreb-Maksimir (ZM) in the eastern suburb, open to the lowland towards the Sava River valley. On average annual and seasonal temperatures are about $1^{\circ} \mathrm{C}$ higher at ZG than ZM. The temperature differences between city centre $(\mathrm{ZG})$ and hilly slopes (ZR) are less than $1^{\circ} \mathrm{C}$, the slopes being colder on average. These differences are small. The suburb meteorological station ZM is open to the low- 
land towards east and exposed to the cold air penetrations and radiation cooling in winter. Consequently, it shows on average the lowest seasonal and annual temperature values compared to the other two observed locations, ZG and ZR, which sites are equally exposed on hilly slopes.

According to the standard deviation values, temperature conditions are more stable from April to October (minimum in June and July, $s d=1.3^{\circ} \mathrm{C}$ at $Z G$, sd $=1.2^{\circ} \mathrm{C}$ at $\mathrm{ZM}$ and $s d=1.1^{\circ} \mathrm{C}$ at $\mathrm{ZR}$ ) than in the cold part of the year from November to March (maximum in February, $s d=2.7^{\circ} \mathrm{C}$ at $\mathrm{ZG}$ and $s d=2.8^{\circ} \mathrm{C}$ at $\mathrm{ZM}$ and $\mathrm{ZR}$ ). Interannual variability in annual as well as seasonal average temperatures is equal at all three locations (Table 1).

During the recent period 1991-2018 mean annual temperature cycles experienced warming in all months. Mean monthly values were above normal (reference monthly mean temperature increased by one standard deviation) for summer months at all three observed locations (ZG - June: $1.8^{\circ} \mathrm{C}$, July: $1.8^{\circ} \mathrm{C}$ and August: $2.1^{\circ} \mathrm{C} ; \mathrm{ZM}$ - June: $2.1^{\circ} \mathrm{C}$, July: $2.1^{\circ} \mathrm{C}$ and August: $2.4^{\circ} \mathrm{C}$; ZR - June: $1.5^{\circ} \mathrm{C}$, July: $1.4^{\circ} \mathrm{C}$ and $\mathrm{Au}-$ gust: $1.7^{\circ} \mathrm{C}$ ) and also for April and May in the city centre $\left(\mathrm{ZG}\right.$ - for both months $\left.1.4^{\circ} \mathrm{C}\right)$ and suburb $(\mathrm{ZM}$ for both months $1.6^{\circ} \mathrm{C}$ ). Consequently mean summer
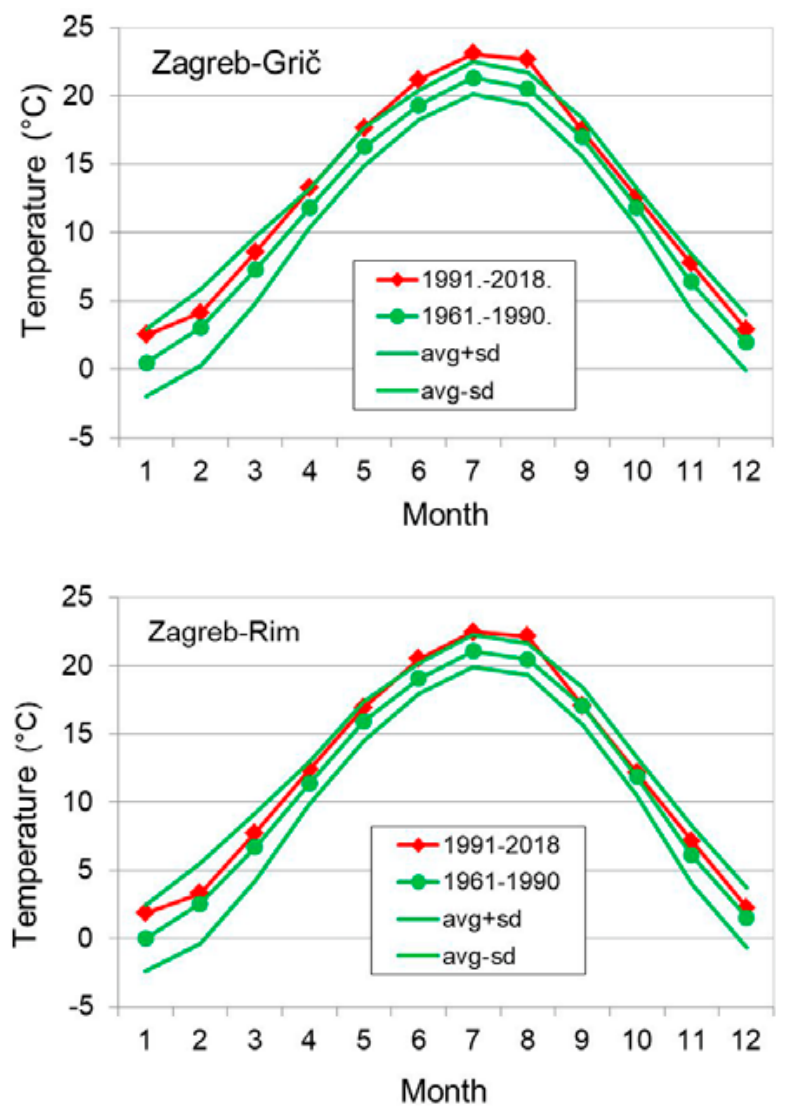

temperatures and mean growing period temperatures as well as mean annual temperatures were above normal values at all locations. On average spring at ZG and autumn at ZM were also significantly warmer (Figure 2 and Table 1).

Warming was most pronounced at the suburb location $(\mathrm{ZM})$ and it can be assumed that this was due to the expanded urbanisation (seasonally: $1.1^{\circ} \mathrm{C}$ to $2.2^{\circ} \mathrm{C}$; in vegetation period $1.8^{\circ} \mathrm{C}$ and annually $1.6^{\circ} \mathrm{C}$ ) (Table 1). In the city center ( $\mathrm{ZG})$ it became warmer on average for seasons $0.9^{\circ} \mathrm{C}$ to $1.9^{\circ} \mathrm{C}$, in vegetation period $1.5^{\circ} \mathrm{C}$ and annually $1.4^{\circ} \mathrm{C}$. The weakest warming was detected at the city slopes at the foot of the Medvednica Mountain (ZR): seasonally $0.4^{\circ} \mathrm{C}$ to $1.5^{\circ} \mathrm{C}$, in vegetation period $1.1^{\circ} \mathrm{C}$ and annually $1.0^{\circ} \mathrm{C}$.

Considering the ten warmest years from the entire period 1961-2018 (58 years), 9 of them were recorded in the $21^{\text {st }}$ century at ZG and ZR and all of them at ZM. Of the ten warmest growing seasons all of them are recorded in the $21^{\text {st }}$ century.

The warming that was identified for seasonal and annual mean values over the Zagreb area is also characteristic for the entire Croatia (Zaninović and Cindrić, 2014). The more detailed study of the trend analysis in mean and extreme annual and seasonal temperatures, as well as in the indices of temperature
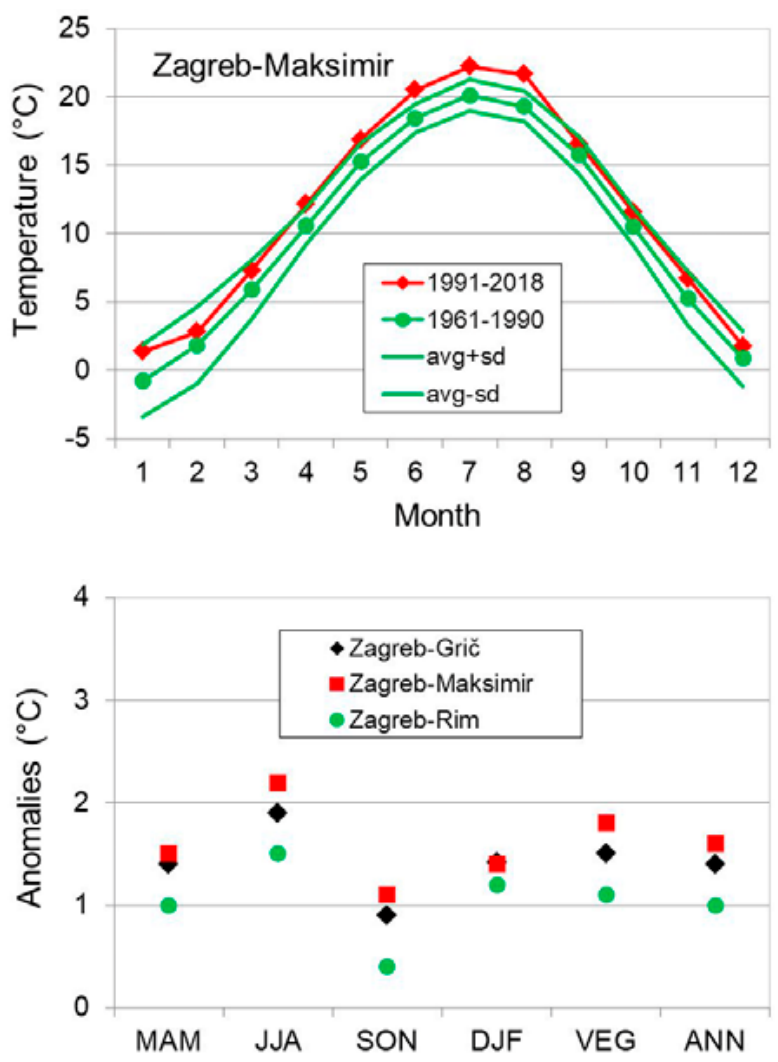

Figure 2. Average monthly air temperature values (avg) for the periods 1991-2018 and 1961-1990, and the intervals avg+sd and avg-sd for the 1961-1990 period (left and right up). Anomalies $\left({ }^{\circ} \mathrm{C}\right.$ ) in mean seasonal, vegetation period and annual temperatures for the period 1991-2018 calculated with respect to the 1961-1990 average (right down) 
Table 1. Basic statistics for seasonal. vegetation period and annual air temperature $\left({ }^{\circ} \mathrm{C}\right)$ and anomalies $\left({ }^{\circ} \mathrm{C}\right)$ in mean seasonal. vegetation period and annual temperatures for the period 1991-2018 calculated with respect to the 1961-1990 average

\begin{tabular}{|c|c|c|c|c|c|c|c|c|c|c|c|c|}
\hline \multicolumn{13}{|c|}{ Zagreb-Grič (157 m a.s.l.) - city centre } \\
\hline & \multicolumn{6}{|c|}{$1961-1990$} & \multicolumn{6}{|c|}{ 1991-2018 } \\
\hline & MAM & JJA & SON & DJF & VEG & ANN & MAM & JJA & SON & DJF & VEG & ANN \\
\hline avg & 11.8 & 20.4 & 11.8 & 1.8 & 17.7 & 11.5 & 13.2 & 22.3 & 12.6 & 3.2 & 19.2 & 12.8 \\
\hline sd & 1.1 & 0.6 & 1.0 & 1.8 & 0.6 & 0.6 & 1.0 & 1.1 & 1.0 & 1.6 & 1.0 & 0.8 \\
\hline $\max$ & 13.5 & 21.7 & 13.8 & 4.6 & 19.0 & 12.5 & 15.0 & 24.6 & 14.4 & 6.9 & 21.3 & 14.1 \\
\hline $\min$ & 9.9 & 19.1 & 9.7 & -2.9 & 16.3 & 10.4 & 11.3 & 20.6 & 10.8 & 0.9 & 17.6 & 11.0 \\
\hline \multicolumn{13}{|c|}{ Zagreb-Maksimir (123 m a.s.l.) - suburb } \\
\hline & \multicolumn{6}{|c|}{$1961-1990$} & \multicolumn{6}{|c|}{ 1991-2018 } \\
\hline & MAM & JJA & SON & DJF & VEG & ANN & MAM & JJA & SON & DJF & VEG & ANN \\
\hline avg & 10.6 & 19.3 & 10.5 & 0.6 & 16.6 & 10.3 & 12.1 & 21.5 & 11.7 & 2.0 & 18.3 & 11.8 \\
\hline sd & 0.9 & 0.6 & 1.0 & 1.8 & 0.6 & 0.5 & 1.0 & 1.0 & 1.0 & 1.5 & 0.9 & 0.8 \\
\hline $\max$ & 12.3 & 20.6 & 12.3 & 3.2 & 17.9 & 11.2 & 13.6 & 24.0 & 13.3 & 5.8 & 20.1 & 13.0 \\
\hline $\min$ & 9.0 & 17.9 & 8.7 & -4.2 & 15.2 & 9.3 & 10.0 & 19.9 & 9.9 & -0.2 & 16.7 & 10.1 \\
\hline \multicolumn{13}{|c|}{ Zagreb-Rim (220 m a.s.l.) - slope } \\
\hline & \multicolumn{6}{|c|}{$1961-1990$} & \multicolumn{6}{|c|}{ 1991-2018 } \\
\hline & MAM & JJA & SON & DJF & VEG & ANN & MAM & JJA & SON & DJF & VEG & ANN \\
\hline avg & 11.4 & 20.2 & 11.7 & 1.3 & 17.5 & 11.2 & 12.4 & 21.7 & 12.1 & 2.5 & 18.6 & 12.2 \\
\hline sd & 1.1 & 0.6 & 1.0 & 1.8 & 0.6 & 0.6 & 1.0 & 1.0 & 1.0 & 1.6 & 0.9 & 0.8 \\
\hline $\max$ & 13.3 & 21.5 & 13.9 & 4.4 & 18.8 & 12.3 & 13.9 & 24.1 & 14.1 & 6.1 & 20.6 & 13.3 \\
\hline $\min$ & 9.3 & 18.9 & 9.5 & -3.3 & 16.2 & 10.2 & 10.6 & 20.2 & 10.3 & -0.2 & 17.2 & 10.4 \\
\hline \multicolumn{13}{|c|}{ Anomalies (1991-2018) in respect to (1961-1990) } \\
\hline & & & & & & & MAM & JJA & SON & DJF & VEG & ANN \\
\hline \multicolumn{7}{|c|}{ Zagreb-Grič } & 1.4 & 1.9 & 0.9 & 1.4 & 1.5 & 1.4 \\
\hline \multicolumn{7}{|c|}{ Zagreb-Maksimir } & 1.5 & 2.2 & 1.1 & 1.4 & 1.8 & 1.6 \\
\hline \multicolumn{7}{|c|}{ Zagreb-Rim } & 1.0 & 1.5 & 0.4 & 1.2 & 1.1 & 1.0 \\
\hline
\end{tabular}

Abbreviations: MAM: March-May; JJA: June-August; SON: September-November; DJF: December-February; VEG: April-September; avg average; sd-standard deviation; max-maximum; min-minimum. grey shaded-values above normal. anomalies: positive-increase

extremes for Croatia was performed for 41 meteorological stations uniformly distributed across Croatia and for the period 1961-2010. The annual air temperature increase is mainly caused by the significant positive summer trends, while the observed trends for winter and spring gave almost equal contribution to the increasing trends of mean maximum temperature. All trends of indices of warm temperature extremes are statistically significant. Warming is also evident in the observed negative trend in the indices of cold temperature extremes, but they are less expressed than the trends of warm indices.

The overall positive trends in annual air temperatures are also recorded for the area of Bosnia and Herzegovina, where the highest trend values are obtained for summer, and then for winter and spring temperatures, while autumn temperatures are subjected to small and mostly positive changes, though mainly insignificant (Trbić et al., 2017). The annual temperature increase in Bosnia and Herzegovina was in the range of $0.2^{-} 0.5^{\circ} \mathrm{C}$ per decade, the summer, winter and spring increase was in the range of respectively $0.5^{-} 0.6^{\circ} \mathrm{C}$, $0.3^{-} 0.5^{\circ} \mathrm{C}$ and $0.2^{-} 0.4^{\circ} \mathrm{C}$ per decade (Trbić et al., 2017). Milošević et al. (2017b) obtained similar results for the Slovenia, where a significant increase in maximum temperature was observed at the annual scale $\left(0.3-0.5^{\circ} \mathrm{C} \cdot \mathrm{per}\right.$ decade). Considering the seasons, the warming was more intense in summer (0.4-0. $7^{\circ} \mathrm{C} \cdot$ per decade) and spring (o.4-0. $6^{\circ} \mathrm{C} \cdot$ per decade) and less intense in winter (0.2-0.6 ${ }^{\circ} \mathrm{C} \cdot$ per decade) and autumn $\left(0.1-0.3^{\circ} \mathrm{C} \cdot\right.$ per decade) in Slovenia according to the authors.

\section{Precipitation}

According to the recent 28-year period 1991-2018, average annual cycle of mean monthly precipitation amounts has continental characteristics at all three locations. During the warm half-year (April to September) this area receives more precipitation than in 
the cold half-year (on average 56\% (ZG and ZR) namely $57 \%(\mathrm{ZM})$ of the annual total) (Figure 3, Table 2). Monthly maximum in annual course appears in September (ZG: $104.5 \mathrm{~mm}, \mathrm{ZM}: 102.2 \mathrm{~mm}, \mathrm{ZR}: 108.6 \mathrm{~mm}$ ) and minimum in February (ZG: $49.2 \mathrm{~mm}, \mathrm{ZM}: 45.8$ mm, ZR: $51.7 \mathrm{~mm}$ ) (Figure 3). Differences between monthly, seasonal and annual precipitation amounts at observed three locations are small but indicate the highest values on the slopes (ZR) and the lowest in the eastern suburb (ZM), which is often found in precipitation shadow for northwest precipitation penetrations. At the annual level the average amount is $2 \%$ higher in the city center than in the eastern suburb and $5 \%$ lower than on the slopes (ZR). Anomalies in monthly precipitation amounts for the recent period 1991-2018 in respect to the reference period for all three locations are similar and small and range between $-16 \%$ to $9 \%$ per month except in September (29\% to 30\%) and in October (26\% to $28 \%$ ). As a consequence, average autumn amount experienced increase of $17 \%$ at ZG and ZR and $20 \%$ at ZM. Decrease (-12\% to $-2 \%)$ in spring, summer and growing season average precipitation, and no change or increase (up to 6\%) in winter
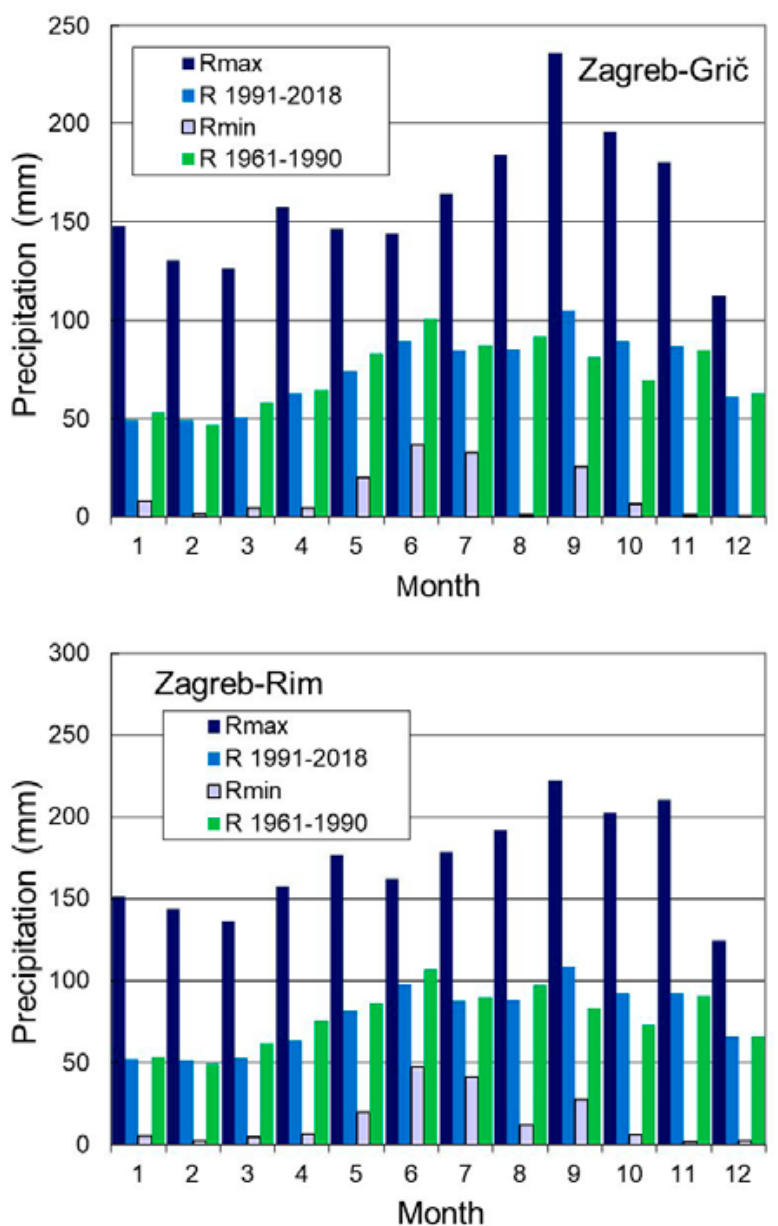

and annual average amounts are present. Variability of seasonal and annual precipitation could be brought into relation with the large-scale atmospheric circulation. Europe climate is under the simultaneous effect of dominant North Atlantic Oscillation (NAO) and the generally weak impact of El Niño Southern Oscillation (ENSO) showing spatial and seasonal dependence (e.g. Herceg Bulić and Ivasić, 2019). At the same time for the Mediterranean region the Mediterranean oscillation (MO) and Western Mediterranean oscillation (WeMO) indices are also applied, as for example, in Milošević et al. (2016). Their results show that the influence of NAO on precipitation variability in Slovenia is smaller than the effects of atmospheric circulations belonging to the Mediterranean area (namely WeMO and MO). The trend analysis in seasonal and annual precipitation in Slovenia indicate the most expressed changes in spring ( -6 to $-10 \%$ per decade) and summer (-4 to $-10 \%$ per decade) precipitation, which are of the same direction (decrease) as was indicated for Zagreb area (Milošević et al., 2016).

In some years there was a significant deviation in monthly amounts from the average precipitation con-
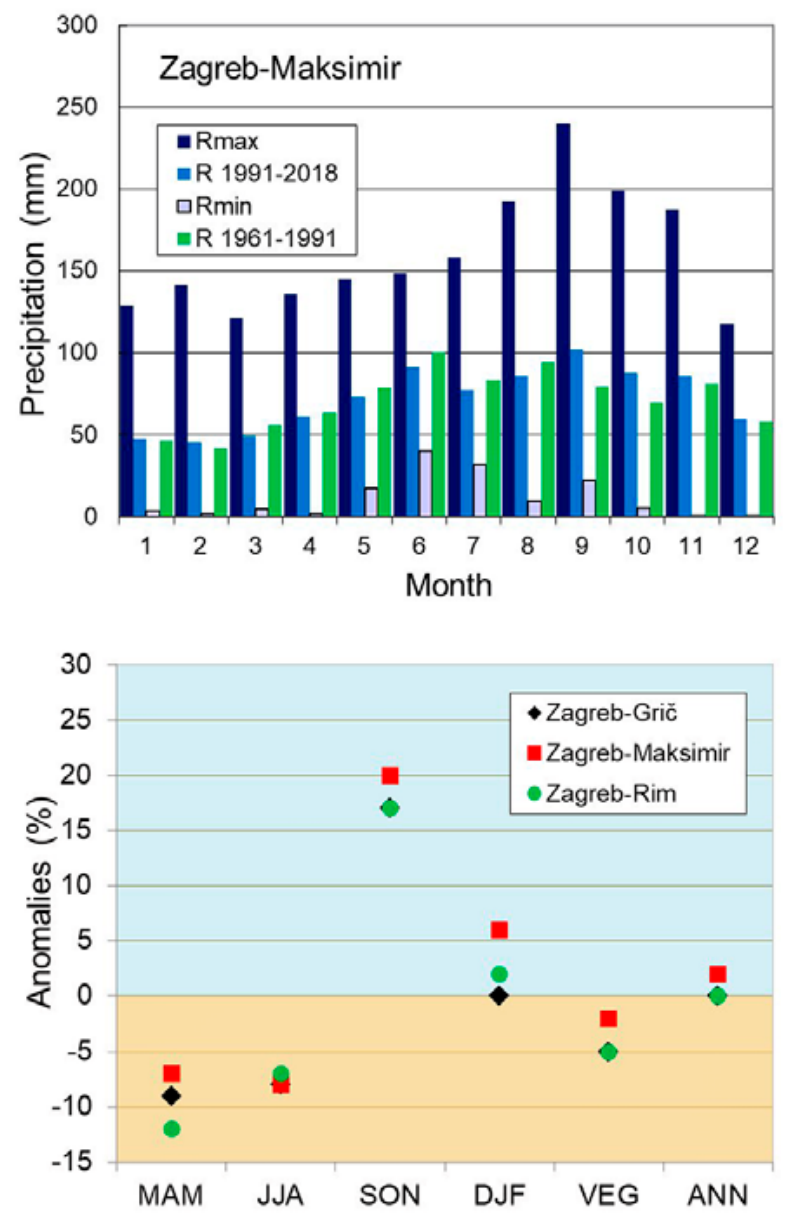

Figure 3. Mean, maximum and minimum monthly precipitation amounts for the period 1991-2018, and mean monthly precipitation amounts for the period 1961-1990 (left and right up). Anomalies of mean seasonal, vegetation period and annual precipitation amounts for the period 1991-2018 calculated with respect to the 1961-1990 average (right down) 
Table 2. Basic statistics for seasonal, vegetation period and annual precipitation amounts $(\mathrm{mm})$ and anomalies (\%) of precipitation amounts and their interannual variability for the period 1991-2018 calculated with respect to the 19611990 average

\begin{tabular}{|c|c|c|c|c|c|c|c|c|c|c|c|c|}
\hline \multicolumn{13}{|c|}{ Zagreb-Grič (157 m a.s.l.) - city centre } \\
\hline & \multicolumn{6}{|c|}{$1961-1990$} & \multicolumn{6}{|c|}{$1991-2018$} \\
\hline & MAM & JJA & SON & DJF & VEG & ANN & MAM & JJA & SON & DJF & VEG & ANN \\
\hline $\mathrm{R}$ & 206 & 280 & 236 & 162 & 508 & 883 & 187 & 258 & 274 & 162 & 485 & 885 \\
\hline sd & 57 & 76 & 77 & 61 & 104 & 136 & 56 & 75 & 86 & 63 & 141 & 156 \\
\hline $\mathrm{CV}$ & 0,28 & 0,27 & 0,33 & 0,38 & 0,20 & 0,15 & 0,30 & 0,29 & 0,31 & 0,39 & 0,29 & 0,18 \\
\hline Rmax & 338 & 516 & 428 & 269 & 752 & 1116 & 291 & 419 & 462 & 329 & 736 & 1234 \\
\hline Rmin & 83 & 157 & 127 & 53 & 327 & 607 & 57 & 129 & 127 & 71 & 201 & 521 \\
\hline \multicolumn{13}{|c|}{ Zagreb-Maksimir (123 m a.s.l.) - suburb } \\
\hline & \multicolumn{6}{|c|}{$1961-1990$} & \multicolumn{6}{|c|}{ 1991-2018. } \\
\hline & MAM & JJA & SON & DJF & VEG & ANN & MAM & JJA & SON & DJF & VEG & ANN \\
\hline $\mathrm{R}$ & 198 & 278 & 230 & 146 & 500 & 853 & 184 & 255 & 270 & 155 & 475 & 867 \\
\hline sd & 54 & 83 & 74 & 56 & 100 & 136 & 52 & 80 & 84 & 59 & 151 & 159 \\
\hline $\mathrm{cV}$ & 0,27 & 0,30 & 0,32 & 0,38 & 0,20 & 0,16 & 0,28 & 0,31 & 0,31 & 0,38 & 0,32 & 0,18 \\
\hline Rmax & 311 & 511 & 408 & 251 & 744 & 1092 & 272 & 422 & 449 & 280 & 814 & 1318 \\
\hline Rmin & 76 & 136 & 106 & 53 & 309 & 558 & 57 & 136 & 115 & 60 & 185 & 517 \\
\hline \multicolumn{13}{|c|}{ Zagreb-Rim (220 m a.s.l.) - slope } \\
\hline & \multicolumn{6}{|c|}{$1961-1990$} & \multicolumn{6}{|c|}{$1991-2018}$. \\
\hline & MAM & JJA & SON & DJF & VEG & ANN & MAM & JJA & SON & DJF & VEG & ANN \\
\hline $\mathrm{R}$ & 225 & 294 & 248 & 169 & 540 & 935 & 198 & 274 & 291 & 172 & 511 & 936 \\
\hline sd & 75 & 86 & 82 & 62 & 115 & 154 & 62 & 84 & 90 & 64 & 165 & 177 \\
\hline $\mathrm{CV}$ & 0,33 & 0,29 & 0,33 & 0,37 & 0,21 & 0,16 & 0,31 & 0,31 & 0,31 & 0,37 & 0,32 & 0,19 \\
\hline Rmax & 457 & 542 & 446 & 287 & 839 & 1255 & 314 & 454 & 471 & 324 & 903 & 1446 \\
\hline Rmin & 106 & 132 & 137 & 73 & 316 & 656 & 58 & 154 & 128 & 77 & 177 & 538 \\
\hline \multicolumn{13}{|c|}{ Precipitation amounts - Anomalies (1991-2018) in respect to (1961-1990) } \\
\hline & & & & & & & MAM & JJA & SON & DJF & VEG & ANN \\
\hline Zagreb & & & & & & & -9 & -8 & 17 & 0 & -5 & 0 \\
\hline Zagreb & simir & & & & & & -7 & -8 & 20 & 6 & -2 & 2 \\
\hline Zagreb & & & & & & & -12 & -7 & 17 & 2 & -5 & 0 \\
\hline \multicolumn{13}{|c|}{ Interannual variability - Anomalies (1991-2018) in respect to (1961-1990) } \\
\hline & & & & & & & MAM & JJA & SON & DJF & VEG & ANN \\
\hline Zagreb & & & & & & & 8 & 7 & -4 & 2 & 43 & 15 \\
\hline Zagreb & simir & & & & & & 3 & 5 & -1 & -1 & 39 & 15 \\
\hline Zagreb & & & & & & & -7 & 5 & -7 & 2 & 51 & 15 \\
\hline
\end{tabular}

Abbreviations: MAM: March-May; JJA: June-August; SON: September-November; DJF: December-February; VEG: April-September; R(mm)average; $s d(\mathrm{~mm})$-standard deviation; $C_{v}$-coefficient of variation; Rmax (mm)-maximum; Rmin (mm)-minimum; anomalies (\%)-negative values $=$ decrease, positive values $=$ increasee

ditions. These led to the large interannual variability, expressed by coefficient of variation, which have been identified for both observed periods and all three locations (Table 2). Anomalies of interannual variability for seasonal precipitation amounts for the recent period in respect to the 1961-1990 period are small and they range between $-7 \%$ and $8 \%$ according to the three observed locations. There is the equal increase in interannual variability for annual precipitation amounts
( $15 \%$ for each location). For vegetation period precipitation amounts anomalies of interannual variability are higher and differ a bit between the locations (ZG: $43 \%$, ZM $39 \%$ and ZR 51\%).

Precipitation time series analysis for the period 19612018 showed that there was no clear grouping of dry or wet years or growing seasons in the 21st century.

The obtained results for precipitation anomalies between the two period in Zagreb are in accordance with 
the results of trend analysis in precipitation amounts and precipitation indices over Croatia for the period 1961-2010 (Gajić-Čapka et al., 2015). They identify large spatial variability and large temporal (seasonal) variability. The results reveal that the changes in annual and seasonal amounts are predominantly weak. A significant trend is detected only for annual amounts (negative) in the mountainous region and for summer (negative) in the mountainous littoral, mountainous region and central hinterland. A significant positive trend for autumn appears in eastern mainland. Negative trends in summer are associated with a decrease in frequency of moderate wet days, in maximal 1- and 5-day precipitation and in an increase in light precipitation. A negative annual trend is mainly caused by a decrease in frequency of very wet days and their contribution to the total precipitation. A positive autumn trend is associated with more very wet days and an increase of their contribution to the total precipitation as well as an increase in maximal 1- and 5-day precipitation.

\section{Rain factor}

According to the modified Lang's rain factor, the suburb (ZM) and the city slopes at the foot of the Medvednica Mountain (ZR) became more arid and characterised by semihumid climate in recent compared to the reference period while the city centre (ZG) in both studied periods has semihumid climate at the annual level (Table 3). Similar results were obtained by Bilandžija et al. (2019) for the Đurđevac area in the north east part of Croatia that become also more arid in recent period 1991-2016 (semihumid climate) compared to the reference period 1961-1990. Comparing the monthly values of rain factors (Table 3), in the re- cent period city centre (ZG) become more arid from February to June and more humid in October; the suburb (ZM) become more arid from May to June and more humid in November while at the city slopes (ZR) period April - June became more arid and period September - November more humid compared to the period $1961-1990$.

\section{Water balance according to Thornthwaite method}

The calculation of evapotranspiration according to Thornthwaite method (Figure 4) showed similar results for the meteorological stations in upper town city centre $(\mathrm{ZG})$ and suburb $(\mathrm{ZM})$. In the recent period 1991-2018, the actual evapotranspiration is lower (by $40 \mathrm{~mm}$ at ZG and by $41 \mathrm{~mm}$ at ZM), as well as the potential evapotranspiration in relation to the 1961-1990 period. Both soil water reserves (by $97 \mathrm{~mm}$ at ZG and $106 \mathrm{~mm}$ at $\mathrm{ZM}$ ) and soil water sufficiency (by $42 \mathrm{~mm}$ at ZG and $54 \mathrm{~mm}$ at $Z M$ ) are higher compared to the reference period $1961-1990$ (Figure 3). At the hilly slopes (ZR), the actual and potential evapotranspiration are lower (by $28 \mathrm{~mm}$ ), while soil water reserves (by $367 \mathrm{~mm}$ ) and soil water sufficiency (by $29 \mathrm{~mm}$ ) are higher in the recent compared to the period 1961 - 1990 (Figure 4). The soil water deficiency in both study periods did not occur at any of the studied locations (Figure 4).

In recent period, the greatest values of actual and potential evapotranspiration, soil water reserves and water sufficiency are indicated at the hilly slopes of the city (ZR). The lowest values of actual and potential evapotranspiration are present at the suburb (ZM), and the lowest values of soil water reserves and water sufficiency in the city centre (ZG).

Table 3. Lang's and Gračanin's rain factor

\begin{tabular}{|c|c|c|c|c|c|c|c|c|c|c|c|c|c|}
\hline Period & 1 & II & III & IV & V & VI & VII & VIII & IX & $x$ & $\mathrm{XI}$ & XII & Year \\
\hline \multicolumn{14}{|c|}{ Zagreb-Grič (157 m a.s.l.) - city centre } \\
\hline \multirow{2}{*}{ 1961- 1990} & 112,6 & 15,2 & 8,0 & 5,5 & 5,1 & 5,2 & 4,1 & 4,4 & 4,8 & 5,9 & 13,2 & 31,8 & 77,1 \\
\hline & ph & ph & h & sh & sh & sh & sa & sa & sa & sh & $\mathrm{h}$ & ph & sh \\
\hline \multirow{2}{*}{$1991-2018$} & 19,5 & 11,9 & 5,9 & 4,7 & 4,2 & 4,2 & 3,7 & 3,7 & 6,0 & 7,0 & 11,1 & 21,0 & 69,0 \\
\hline & ph & h & sh & sa & sa & sa & sa & sa & sa & $\mathrm{h}$ & $\mathrm{h}$ & ph & sh \\
\hline \multicolumn{14}{|c|}{ Zagreb-Maksimir (123 m a.s.l.) - suburb } \\
\hline \multirow{2}{*}{ 1961- 1990} & & 22,7 & 9,4 & 6,0 & 5,2 & 5,4 & 4,1 & 4,9 & 5,0 & 6,6 & 15,4 & 66,2 & 83,0 \\
\hline & & ph & $\mathrm{h}$ & sh & sh & sh & sa & sa & sh & $\mathrm{h}$ & $\mathrm{ph}$ & $\mathrm{ph}$ & $\mathrm{h}$ \\
\hline \multirow{2}{*}{$1991-2018$} & 34,5 & 16,4 & 6,7 & 5,0 & 4,3 & 4,4 & 3,5 & 4,0 & 6,2 & 7,6 & 12,7 & 33,6 & 73,3 \\
\hline & ph & ph & $\mathrm{h}$ & sh & sa & sa & sa & sa & sh & $\mathrm{h}$ & $\mathrm{h}$ & ph & sh \\
\hline \multicolumn{14}{|c|}{ Zagreb-Rim (220 m a.s.l.) - slope } \\
\hline \multirow{2}{*}{ 1961- 1990} & & 19,2 & 9,3 & 6,7 & 5,4 & 5,6 & 4,3 & 4,7 & 4,9 & 6,2 & 14,7 & 42,6 & 83,8 \\
\hline & & ph & $\mathrm{h}$ & $\mathrm{h}$ & sh & sh & sa & sa & sa & sh & $\mathrm{ph}$ & ph & $\mathrm{h}$ \\
\hline \multirow{2}{*}{$1991-2018$} & 27,5 & 15,6 & 6,8 & 5,1 & 4,8 & 4,8 & 3,9 & 4,0 & 6,4 & 7,6 & 12,9 & 28,9 & 76,8 \\
\hline & $\mathrm{ph}$ & $\mathrm{ph}$ & $\mathrm{h}$ & sh & sa & sa & sa & sa & sh & $\mathrm{h}$ & $\mathrm{h}$ & ph & sh \\
\hline
\end{tabular}

Abbreviations: ph-perhumid; h-humid; sh-semihumid; sa-semiarid 
Zagreb-Grič (157 m a.s.l.) - city centre
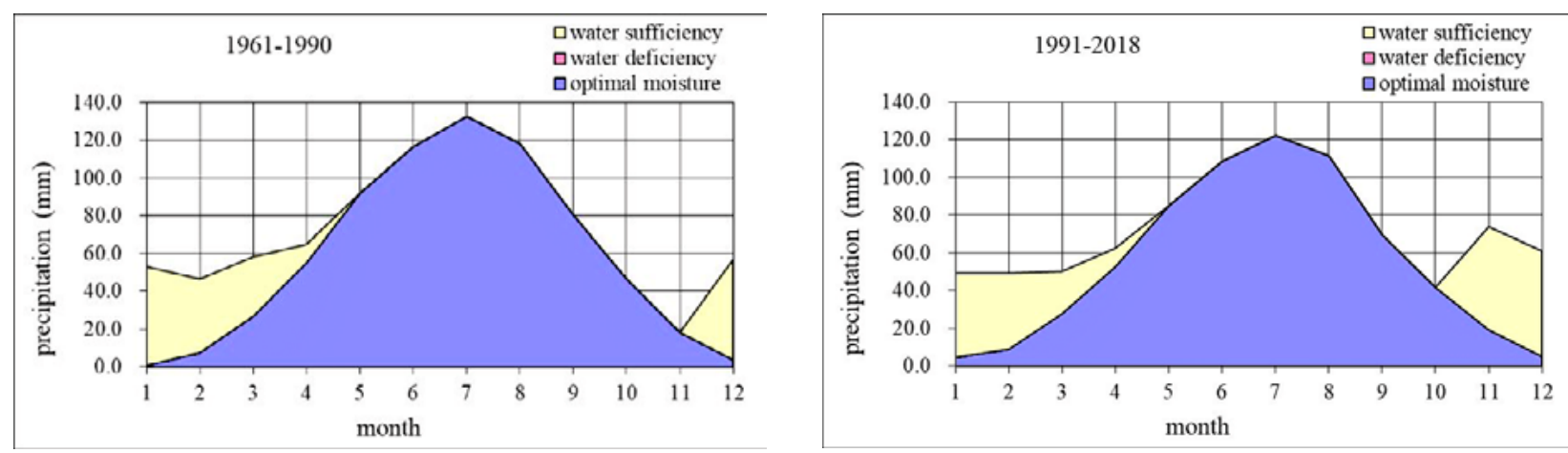

Zagreb-Maksimir (123 m a.s.l.) - suburb
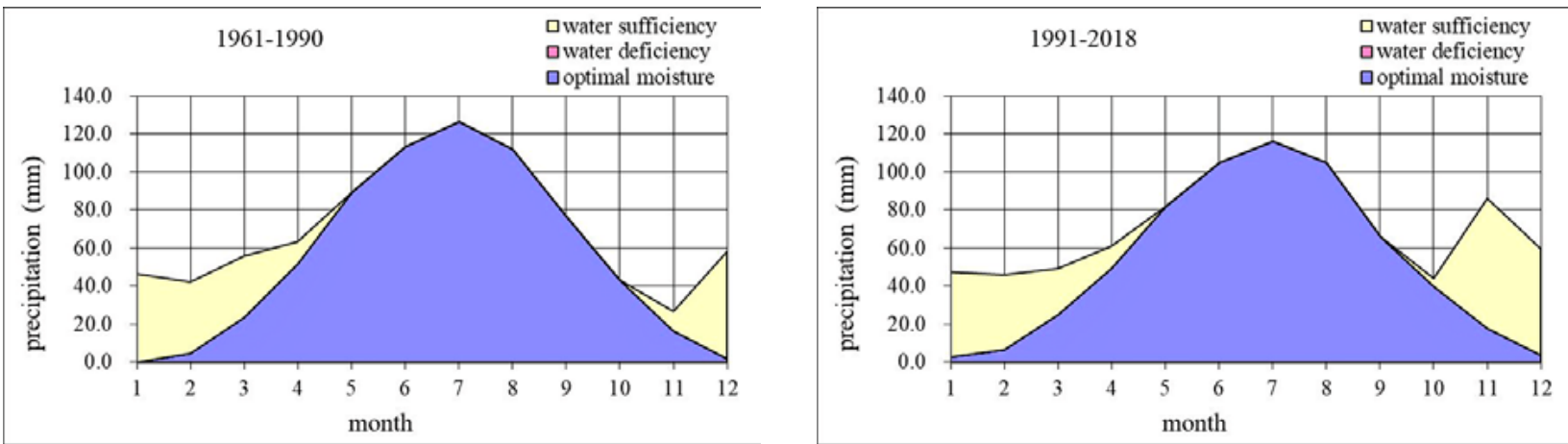

Zagreb-Rim (220 m a.s.l.) - slope
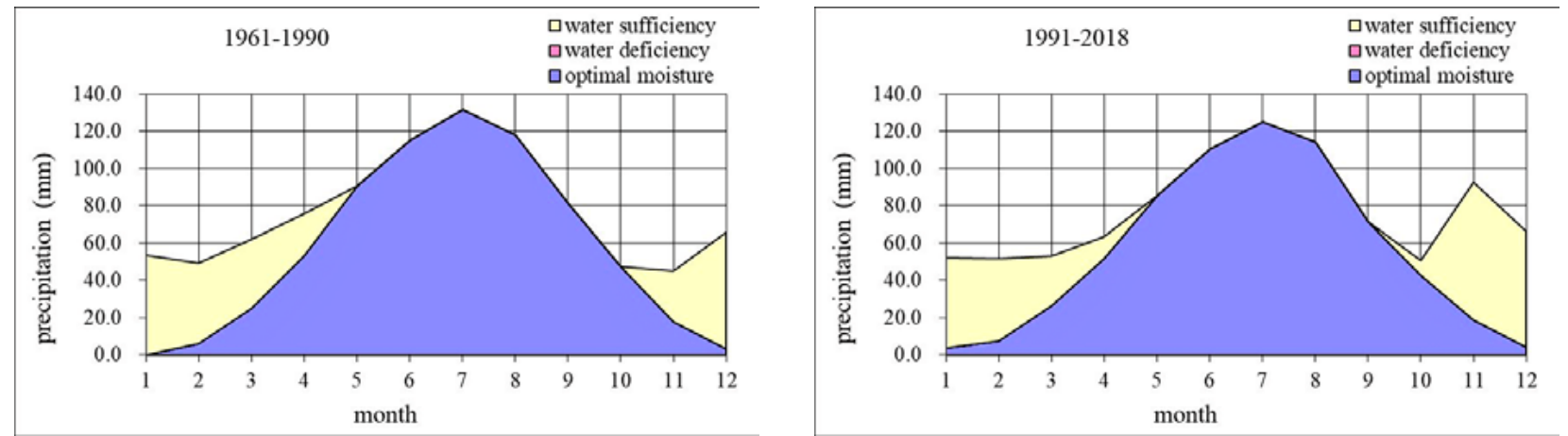

Figure 4. Evapotranspiration for the periods 1961-1990 (left) and 1991-2018 (right)

Due to higher soil water reserves and soil water sufficiency, the drainage of sufficient water should be considered in future planning of green urban infrastructure in order to prepare soils for receiving and managing higher quantity of precipitation and provide optimal growth conditions for green areas.

\section{Index of aridity according to UNEP}

According to the index of aridity (Table 4), the drought conditions at all three locations did not change over the time and were the same between locations. In the city centre $(\mathrm{ZG})$ in the driest year of the reference period, usually humid area was semiarid in March, May, August and October while June and July were subhumid. In the wettest year of the reference period, August was the driest month and October was semiarid compared to the reference period. In the driest year of recent period 1991-2018, August and November were arid and May semiarid, compared to the average 19611990. In the wettest year of the recent period, only usually humid March was subhumid.

In the driest year of reference period at the suburb, usually humid area was subhumid in September, semiarid in May and October, while June was the driest. In the wettest year of reference period August was the driest month and October was semiarid compared to reference period. In the driest year of recent period 1991-2018, July and September were subhumid, August was arid, and November hyperarid compared to the 1961-1990 average. In the wettest year of recent period, only usually humid March was subhumid. 
Table 4. Index of aridity for the periods average, driest and wettest year in periods 1961-1990 and 1991-2018

\begin{tabular}{|c|c|c|c|c|c|c|c|c|c|c|c|c|c|}
\hline \multirow{2}{*}{\multicolumn{2}{|c|}{ Series of met. data }} & \multicolumn{9}{|c|}{ Month } & \multicolumn{3}{|c|}{ Annually, mm } \\
\hline & & III & IV & v & VI & VII & VIII & IX & $\mathrm{x}$ & $\mathrm{XI}$ & P* & $D^{*}$ & $\mathrm{~S}^{*}$ \\
\hline \multicolumn{14}{|l|}{ Zagreb-Grič } \\
\hline \multirow{3}{*}{1961 - 1990} & Average & 2,16 & 1,18 & 0,90 & 0,87 & 0,66 & 0,78 & 1,01 & 1,49 & 4,66 & 882,8 & 0 & 185,6 \\
\hline & Dry 1973 & 0,43 & 1,90 & 0,24 & 0,61 & 0,61 & 0,26 & 1,15 & 0,45 & 4,30 & 607,3 & 179 & 103,0 \\
\hline & Rainy 1962 & 7,05 & 1,91 & 0,92 & 0,84 & 1,08 & 0,05 & 1,46 & 0,32 & 16,90 & 1115,9 & 51 & 457,3 \\
\hline \multirow{3}{*}{$1991-2018$} & Average & 1,83 & 1,19 & 0,87 & 0,82 & 0,69 & 0,76 & 1,51 & 2,12 & 4,46 & 885,3 & 0 & 228,2 \\
\hline & Dry 2011 & 1,54 & 0,71 & 0,46 & 0,82 & 0,67 & 0,15 & 0,69 & 2,03 & 0,08 & 520,8 & 138 & 29,8 \\
\hline & Rainy 2014 & 0,58 & 1,34 & 1,45 & 1,36 & 0,86 & 1,29 & 3,35 & 2,73 & 3,75 & 1233,8 & 0 & 594,5 \\
\hline \multicolumn{14}{|c|}{ Zagreb-Maksimir } \\
\hline \multirow{3}{*}{$1961-1990$} & Average & 2,36 & 1,23 & 0,88 & 0,88 & 0,66 & 0,85 & 1,04 & 1,61 & 4,96 & 852,3 & 0 & 194,2 \\
\hline & Dry 1971 & 5,83 & 0,95 & 0,43 & 0,66 & 0,19 & 1,05 & 0,62 & 0,22 & 4,04 & 558,2 & 152 & 84,3 \\
\hline & Rainy 1962 & 6,83 & 2,23 & 1,01 & 0,72 & 1,13 & 0,06 & 1,42 & 0,31 & 16,15 & 1092,2 & 40 & 461,2 \\
\hline \multirow{3}{*}{$1991-2018$} & Average & 1,98 & 1,24 & 0,89 & 0,87 & 0,67 & 0,82 & 1,54 & 2,21 & 4,79 & 866,7 & 0 & 248,5 \\
\hline & Dry 2011 & 1,55 & 0,81 & 0,91 & 0,66 & 0,59 & 0,15 & 0,53 & 2,21 & 0,05 & 520,8 & 138 & 29,8 \\
\hline & Rainy 2014 & 0,60 & 1,38 & 2,08 & 1,55 & 1,50 & 1,29 & 3,00 & 0,60 & 1,38 & 1317,8 & 0 & 712,3 \\
\hline \multicolumn{14}{|l|}{ Zagreb-Rim } \\
\hline \multirow{3}{*}{$1961-1990$} & Average & 2,49 & 1,43 & 0,96 & 0,93 & 0,68 & 0,83 & 1,03 & 1,55 & 5,11 & 934,9 & 0 & 246,7 \\
\hline & Dry 1971 & 7,30 & 1,01 & 0,48 & 0,82 & 0,35 & 0,96 & 0,75 & 0,21 & 4,60 & 655,9 & 118 & 109,9 \\
\hline & Rainy 1980 & 3,18 & 7,00 & 1,02 & 0,51 & 0,59 & 0,48 & 0,95 & 3,61 & 12,11 & 1254,5 & 93 & 636,2 \\
\hline \multirow{3}{*}{$1991-2018$} & Average & 2,02 & 1,23 & 0,96 & 0,89 & 0,70 & 0,78 & 1,52 & 2,17 & 4,92 & 936,1 & 0 & 275,5 \\
\hline & Dry 2011 & 1,64 & 0,80 & 0,42 & 0,68 & 0,62 & 0,17 & 0,54 & 2,14 & 0,24 & 537,5 & 173 & 59,6 \\
\hline & Rainy 2014 & 0,51 & 1,35 & 2,41 & 1,38 & 1,56 & 1,23 & 3,29 & 3,25 & 3,62 & 1446,0 & 0 & 792,4 \\
\hline
\end{tabular}

*P - Precipitation in $\mathrm{mm}$, PET - potential evapotranspiration in $\mathrm{mm}$; D - water deficiency in $\mathrm{mm}, \mathrm{S}$ - water surplus in $\mathrm{mm}$

subhumid $\left(0,50<\mathrm{Al}_{U}<0,65\right)$

At the hilly area of Zagreb city, in the driest year of reference period usually humid area was semiarid in May, July and October and in the wettest year of past period June and July were subhumid and $\mathrm{Au}-$ gust was semiarid compared to reference period. August was the driest, July and September subhumid and May and November semiarid in the driest year of recent period 1991-2018. In the wettest year of recent period, only March was subhumid compared to the average of the recent period.

According to modified Lang's rain factor, the suburb (ZM) and the slopes (ZR) become more arid in recent period, primarily as a result of warming. According to evapotranspiration by Thornthwaite method and index of aridity, none of studied locations experienced water deficiency. Mentioned could be attributed to the soil water reserves and soil water sufficiency that were higher in the recent period at all three locations compared to reference period.

Szabo et al. (2019) identified the tendencies between 1960 and 2010 in the Carpathians region and revealed that monthly average temperature, maximum temperature and evapotranspiration had positive trends in all seasons except autumn, and the precipitation had a positive trend, but negative values in winter.
Furthermore, authors identified the western part of Hungary and the eastern part of Croatia as most sensitive regions for the predicted climatic changes.

\section{Thresholds of cardinal temperatures for vegetation periods with temperatures above $5,10,15$ and $20^{\circ} \mathrm{C}$}

The beginning, end and duration in days of the vegetation periods with temperatures above 5, 10,15 and $20^{\circ} \mathrm{C}$ are presented in Table 5. The period with temperatures above $5^{\circ} \mathrm{C}$ is prolonged by 16 days in the city centre $(\mathrm{ZG})$ and at the suburb $(\mathrm{ZM})$, while at the hilly slopes (ZR) it is prolonged by 13 days in the recent period compared to $1961-1990$ period. Considering the period with temperatures above $10^{\circ} \mathrm{C}$, it is prolonged in the city centre $(\mathrm{ZG})$ and at the suburb (ZM) by 15 days and at the city slopes (ZR) by 9 days in the period 1991 - 2018 compared to the reference period. The period with temperatures above $15{ }^{\circ} \mathrm{C}$ is prolonged by 12,16 and 8 days respectively in the city centre (ZG), at the suburb (ZM) and at the hilly slopes (ZR). The greatest change in the duration of vegetation period with temperatures above $20^{\circ} \mathrm{C} \mathrm{oc}$ curred at the suburb (ZM) where it is prolonged by 69 days, followed by city centre (ZG) where it is prolonged by 32 days, and at the city slopes (ZR) where 
Table 5. Vegetation periods with cardinal temperatures of $5,10,15$ and $20^{\circ} \mathrm{C}$

\begin{tabular}{|c|c|c|c|c|c|c|c|c|c|c|c|c|}
\hline \multirow[t]{3}{*}{ Period } & \multicolumn{12}{|c|}{ Cardinal temperature, ${ }^{\circ} \mathrm{C}$} \\
\hline & \multicolumn{3}{|c|}{5} & \multicolumn{3}{|c|}{10} & \multicolumn{3}{|c|}{15} & \multicolumn{3}{|c|}{20} \\
\hline & B & $\mathrm{E}$ & L & B & $\mathrm{E}$ & L & B & $\mathrm{E}$ & $\mathrm{L}$ & B & $\mathrm{E}$ & $\mathrm{L}$ \\
\hline \multicolumn{13}{|c|}{ Zagreb-Grič (157 m a.s.l.) - city centre } \\
\hline $1961-1990$ & 28.11 & 24.XI & 269 & 2.IV & $25 . x$ & 206 & $6 . \mathrm{V}$ & 27.IX & 144 & 25.VI & 20.VIII & 56 \\
\hline $1991-2018$ & 20.11 & 2.XII & 285 & 24.1II & $31 . x$ & 221 & 27.IV & $30.1 \mathrm{X}$ & 156 & 4.VI & 31.VIII & 88 \\
\hline \multicolumn{13}{|c|}{ Zagreb-Maksimir (123 m a.s.l.) - suburb } \\
\hline $1961-1990$ & 9.111 & 17.XI & 253 & 10.IV & 18. $\mathrm{X}$ & 191 & $13 . \mathrm{V}$ & 19.IX & 129 & 13.VII & 20.VII & 7 \\
\hline $1991-2018$ & 2.111 & $26 . X I$ & 269 & $2 . I V$ & $25 . x$ & 206 & $3 . V$ & $25.1 \mathrm{X}$ & 145 & $10 . \mathrm{VI}$ & 25.VIII & 76 \\
\hline \multicolumn{13}{|c|}{ Zagreb-Rim (220 m a.s.l.) - slope } \\
\hline $1961-1990$ & 4.111 & 22.XI & 263 & $5.1 \mathrm{~V}$ & $25 . x$ & 203 & $9 . \mathrm{V}$ & $27.1 \mathrm{X}$ & 141 & $29 . \mathrm{VI}$ & 19.VIII & 51 \\
\hline $1991-2018$ & 25.11 & 28.XI & 276 & 30.111 & $28 . x$ & 212 & $2 . V$ & $28.1 X$ & 149 & 10.VI & 28.VIII & 79 \\
\hline
\end{tabular}

Abbreviations: $B$ - beginning; $E$ - end; $L$ - length of the period in days

it is prolonged by only 8 days. The greatest average change in duration of vegetation periods experienced the suburb of Zagreb city (ZM), followed by city centre $(\mathrm{ZG})$ and the lowest change experienced hilly slopes of the city (ZR).

Similar results were obtained for other locations in Croatia, as well as Europe. Longer vegetation periods with temperatures above 5,10 and $15^{\circ} \mathrm{C}$ (respectively by 16,14 and 13 days) were observed in north east part of Croatia (Đurđevac) by Bilandžija et al. (2019). At the highest meteorological station in Croatia (Zavižan, $1594 \mathrm{~m}$ a.s.l.), longer vegetation periods in autumn are observed by Vučetić and Vučetić (2003). Earlier beginning of olive and syringa flowering in southern part of the Croatian coast (Hvar, Dubrovnik) has also been detected (Vučetić and Vučetić, 2005; Jelić and Vučetić, 2011). In neighbouring country Slovenia, vegetation periods with temperatures above 5 and $10^{\circ} \mathrm{C}$ prolonged between 20 and 25 days/51y under the influence of high positive trends of temperature parameters. Across biogeographical regions of Europe, the flowering phenology of plant species was examined by Templ et al. (2017) in order to identify their spatiotemporal patterns. The authors concluded that significant species-specific advancements in plant flowering onsets within the Continental ( 3 to 8.3 days), Alpine ( 2 to 3.8 days) and by the highest magnitude in the Boreal biogeographical regions (2.2 to 9.6 days per decades), while less pronounced responses were detected in the Pannonian and Mediterranean regions

\section{Conclusions}

Average annual temperature regime for three locations in the Zagreb city area show differences in the interval $0.0^{\circ} \mathrm{C}$ to $1.4^{\circ} \mathrm{C}$ for monthly, $0.3^{\circ} \mathrm{C}$ to $1.2^{\circ} \mathrm{C}$ for seasonal and $0.4^{\circ} \mathrm{C}$ to $1.0^{\circ} \mathrm{C}$ for annual averages. ZagrebGrič (ZG) in the upper town of the central urban area is the warmest location and the coldest location is $\mathrm{Za}$ greb-Maksimir (ZM) in the eastern suburb, open to the lowland towards the Sava River valley. Differences in precipitation amounts are small but indicate the highest values on the slopes (ZR) and the lowest in the eastern suburb (ZM), which is often found in precipitation shadow for northwest precipitation penetrations. The anomalies in precipitation interannual variability between the two periods are pronounced for annual amounts ( $15 \%$ at each location) and for vegetation period (39\% to $51 \%)$.

The climate change results for annual and seasonal average temperatures and precipitation amounts, defined as the difference between the recent 19912018 period and the reference $1961-1990$ period, are compared with the projections for the near future climate (2011-2040) for the area under consideration which are inferred from the simulated climate changes over Europe (MZOIP, 2014). The comparison with the ENSEMBLES RCM simulations indicate that the warming was in the range of projected increase $\left(1.0^{\circ} \mathrm{C}\right.$ to $\left.1.5^{\circ} \mathrm{C}\right)$ for spring, weaker than the projected increase for autumn $\left(1.0^{\circ} \mathrm{C}\right.$ to $\left.1.5^{\circ} \mathrm{C}\right)$ and for winter $\left(1.5^{\circ} \mathrm{C}\right.$ to $\left.2^{\circ} \mathrm{C}\right)$, and stronger than the projected increase for summer $\left(1.0^{\circ} \mathrm{C}\right.$ to $\left.1.5^{\circ} \mathrm{C}\right)$. According to the ENSEMBLES RCM simulations spring, summer and autumn precipitation amounts are projected to change in the interval $-5 \%$ to $+5 \%$, over the observed area. Decrease in spring and summer precipitation indicated in the recent period at all three locations is stronger $(-12 \%$ to $-7 \%)$ than the projected change as well as increase in autumn precipitation amounts of $17 \%$ at $Z$ G and ZR and $20 \%$ at ZM. No change (ZG) and slight increase (ZM: 6\%, ZR: $2 \%$ ) in winter precipitation are in the range of projected increase in 
winter precipitation amount of up to $15 \%$ for a part of the observed area.

The rain factor experienced no change in the city centre $(\mathrm{ZG})$ while the suburb location $(\mathrm{ZM})$ and the city hilly slopes (ZR) become more arid with semihumid climate in recent period compared to the reference period 1961-1990. At all the studied locations (ZG, $\mathrm{ZM}, \mathrm{ZR})$, the actual and potential evapotranspiration is lower, the soil water reserves and soil water sufficiency are greater in the recent compared to the referent period, while soil water deficiency in both studied periods does not occur. The greatest actual and potential evapotranspiration as well as water sufficiency occur at the hilly slopes (ZR), and the greatest soil water reserves in the city centre (ZG). According to the index of aridity, the drought conditions at all three loca- tions did not change over the time and were the same between locations. At all studied locations in the $\mathrm{Za}-$ greb city (ZG, ZM, ZR), the periods with temperatures above $5,10,15$ and $20^{\circ} \mathrm{C}$ is prolonged between 13 $16,9-15,12-18$ and 8-69 days respectively in the recent period 1991 - 2018 compared to reference period 19611990. The greatest average change in duration of vegetation periods experienced the suburb (ZM) and the lowest one the hilly slopes of the city (ZR).

Indicated changes in agroclimatic conditions (warming, no change in mean annual precipitation, lower evapotranspiration, higher soil water reserves and longer vegetations periods) should be considered in the planning process of green urban infrastructure in order to mitigate and adapt to climate change in the best possible way.

\section{References}

Bajšanski, I. V., Milošević, D. D., \& Savić, S. M. (2015). Evaluation and improvement of outdoor thermal comfort in urban areas on extreme temperature days: Applications of automatic algorithms. Building and Environment, 94, 632-643.

Bilandžija, D., Bašić, F., Kisić, I., Mesić, M., Zgorelec, Ž., Šestak, I., Perčin, A., \& Bogunović, I. (2019). Agroklimatski pokazatelji kao indikator klimatskih promjena na području Đurđevačkih pijesaka, str. 127-148. In: Zbornik radova sa znanstvenog skupa: Đurđevački pijesci - geneza, stanje i perspektive. Hrvatska Akademija znanosti i u umjetnosti, Zavod za znanstvenoistraživački i umjetnički rad Koprivničko-križevačke županije u Križevcima, Znanstveno vijeće za poljoprivredu i šumarstvo, Znanstveno vijeća za zaštitu prirode. Đurđevac, pp 29-30. lipanj 2017. Zagreb-Križevci, 2019

Butorac, A. (1976). Opća proizvodnja bilja (praktikum). Zagreb, Sveučilište u Zagrebu Agronomski fakultet.

Demuzere, M., Orru, K., Heidrich, O., Olazabal, E. Geneletti, D., Orru, H., Bhave, A.G., Mittal, N. Feliu, E., \& Faehnle, M. (2014). Mitigating and adapting to climate change: Multi-functional and multi-scale assessment of green urban infrastructure. Journal of Environmental Management, 146, 107-115. DHMZ (2019). Srednje mjesečne vrijednosti i ekstremi. Meteorological and Hydrological Service of Croatia. https://meteo.hr/klima.php?section=klima podaci\&param=k1\&Grad=zagreb maksimir (29.12.2019)

Farrugia, S., Hudson, M., \& McCulloch, L. (2013). An evaluation of flood control and urban cooling ecosystem services delivered by urban green infrastructure. International Journal of Biodiversi- ty Science, Ecosystem Services \& Management, 9(2), 136-145.

Gajić-Čapka, M. (1982) Varijabilnost prosječnog oborinskog režima šire zagrebačke regije (Variability of average precipitation regime over the wider Zagreb region). Rasprave, 17, 23-40

Gajić-Čapka, M., \& Cindrić, K. (2008). Klimatološkostatistička analiza oborine na širem zagrebačkom području (Climatological-statistical analysis of precipitation over the broader Zagreb area), Zbornik radova sa Savjetovanja "Zagrebačke vode", 4. i 5. prosinca 2008., Zagreb, Kigen d.o.o., pp 15-25.

Gajić-Čapka, M., Cindrić, K., \& Pasarić, Z. (2015). Trends in precipitation indices in Croatia, 19612010. Theoretical and applied climatology, 121(1/2), 167-177 doi:10.1007/soo704-014-1217-9

Gračanin, M. (1950) Mjesečni kišni faktori i njihovo značenje u pedološkim istraživanjima, Izdavački zavod Jugoslavenske akademije znanosti i umjetnosti. Poljoprivredna znanstvena smotra, 12, 51-66.

Herceg Bulić, I., \& Ivasić, S. (2019) Is it possible to distinguish an ENSO-related signal from NAO in European climate anomalies? EMS Annual Meeting, Copenhagen, Denmark, 2019.

Jelić, M., \& Vučetić, V. (2011). Utječe li promjena klime na početak cvjetanja jorgovana? Hrvatski meteorološki časopis, 46, 45-53

Milošević, D. D., Savić, S. M., Pantelić, M., Stankov, U., Žiberna, I., Dolinaj, D., \& Leščešen, I. (2016). Variability of seasonal and annual precipitation in Slovenia and its correlation with large-scale atmospheric circulation. Open geosciences, 8(1), 593-605.

Milošević, D., Bajšanski, I. V., \& Savić, S. M. (2017a). Influence of changing trees locations on thermal 
comfort on street parking lot and footways. Urban forestry and urban greening, 23, 113-124.

Milošević, D., Savić, M., Stankov, U., Žiberna, I., Pantelić, M., Dolinaj, D., \& Leščešen, I. (2017b). Maximum temperatures over Slovenia and their relationship with atmospheric circulation patterns. Geografie-Sbornik CGS.

Milošević, D., Žiberna, I., \& Savić, S. (2013). Analysis of the climate change in Slovenia: Changes in plant development under the influence of meteorological parameters in the period 1961-2011-part II. Bulletin of the Serbian geographical society, 93(2).

Ministry of Environmental and Nature Protection (MZOIP) (2014). Sixth National Communication and First Biennial Report of the Republic of Croatia under the United Nation Framework Convention on the Climate Change. Republic of Croatia Ministry of Environmental and Nature Protection (MZOIP), Zagreb, pp 247. http://unfccc.int/files/national reports/annex i natcom /application/pdf/hrv nc6. pdf

Ongoma, V., Muange, K. P., \& Zablon, W. S. (2016). Potential effects of urbanization on urban thermal comfort, a case study of Nairobi city, Kenya: A review. Geographica Pannonica, 20(1), 19-31.

Penzar, I., \& Penzar, B. (2000) Agrometeorologija. Zagreb, Školska knjiga.

Perčec Tadić, M., Gajić-Čapka, M., Zaninović, K., \& Cindrić, K. (2013) Drought Vulnerability in Croatia. Agriculture conspectus scientificus, 79(1), 31-38.

Sokol Jurković, R. (2011). Promjenjivost godišnje količine oborine na širem zagrebačkom području i dijelu središnje Hrvatske (Variability in annual precipitation amounts over the broader Zagreb region and a part of central Croatia). 5. Hrvatska konferencija o vodama s medunarodnim sudjelovanjem - Hrvatske vode pred izazovom klimatskih promjena, Opatija, 18. -21. svibnja 2011.

Stewart, I. D., \& Oke, T. R. (2012). Local climate zones for urban temperature studies. Bulletin of the American Meteorological Society, 93(12), 1879-1900.

Szabó, S., Szopos, N.M., Bertalan-Balázs, B., László, E., Milošević, D.D., Conoscenti, C., \& Lázár, I. (2019). Geospatial analysis of drought tendencies in the Carpathians as reflected in a 50-year time series. Hungarian Geographical Bulletin, 68(3), 269-282.
Takács, Á., Kiss, M., Gulyás, Á., Tanács, E., \& Kántor, N. (2016). Solar permeability of different tree species in Szeged, Hungary. Geographica Pannonica, 2o(1), 32-41.

Templ, B., Templ, M., Filzmoser, P., Lehoczky, A., Baksiene, E., Fleck, S., Gregow, H., Hodzic, S., Kalvane, G., Kubin, E. \& Palm, V., (2017). Phenological patterns of flowering across biogeographical regions of Europe. International journal of biometeorology, 61(7), 1347-1358 doi:10.1007/s00484-017-1312-6

Trbić, G., Popov, T., \& Gnjato, S. (2017). Analysis of air temperature trends in Bosnia and Herzegovina. Geographica Pannonica, 21(2), 68-84.

United Nations Environment Programme (UNEP) (1992). World Atlas of Desertification. Edward Arnold, London, pp. 69.

Velasco, E., \& Roth, M. (2010). Cities as net sources of $\mathrm{CO}_{2}$ : review of atmospheric $\mathrm{CO}_{2}$ exchange in urban environments measured by Eddy covariance technique. Geography Compass, 4(9), 1238-1259.

Vučetić, V., \& Vučetić, M. (2003) Fenološke značajke na području Zavižana. Šumarski list, 7-8, 359-372.

Vučetić, V., \& Vučetić, M. (2005). Variations of phenological stages of olive-trees along the Adriatic coast. Periodicum biologorum, 107(3), 335-340

World Meteorological Organization - WMO (2011). Guide to Climatological Practices, WMO No. 100, pp 115. http://www.wmo.int/pages/prog/wcp/ccl/ documents/WMO 100 en.pdf

World Meteorological Organization - WMO (2012) Technical Regulations, WMO-No. 49, Volume I: General Meteorological Standards and Recommended Practices, pp 83. http://library.wmo.int/ pmb ged/wmo 49-v1-2012 en.pdf

Zaninović, K., Gajić-Čapka, M., Perčec Tadić, M., Vučetić, M., Milković, J., Bajić, A., Cindrić, K., Cvitan, L., Katušin, Z., Kaučić, D., Likso, T., Lončar, E., Lončar, Ž., Mihajlović, D., Pandžić, K., Patarčić, M., Srnec, L., \& Vučetić, V. (2008). Klimatski atlas Hrvatske / Climate atlas of Croatia 1961-1990., 1971-2000. Državni hidrometeorološki zavod, Zagreb, pp 200. http://klima.hr/razno e.php?id=news\&param=atlas e

Zaninović, K., \& Cindrić, K. (2014). Changes in indices of temperature extremes in Croatia, 1961-2010. EMS Annual Meeting Abstracts, Vol.11, Prag: Czech Republic, 2014. pp. EMS2014-80 